Murmurations:

Journal of

Transformative

Systemic

Practice

\title{
Social research as a process of interaction
}

\author{
Laura Fruggeri
}

Volume 3

Issue 2

Spring 2021

Keywords:

social

constructionism,

constructivism,

Bateson,

epistemology,

reflexivity,

double description,

social research

Citation Link
The revival paper for this issue was originally written in 1994 for a conference about the contribution of Bateson to social research. Scholars from different fields of the social sciences (Psychology, Sociology, Anthropology, Philosophy, Education) were invited to participate.

It is followed by four contemporary responses from Sharon Bond, Sheila McNamee, Hugh Palmer and Gail Simon.

The original Italian reference for this paper is:

Fruggeri, Laura (1994) La ricerca sociale come processo di interazione. In Sergio Manghi (a cura di) Attraverso Bateson: ecologia della mente e relazioni sociali. Milano, Anabasi, 87-102. It is published here with respect to Sergio Manghi.

\begin{abstract}
"Constructivism", in the social sciences, is a large container where, conventionally, but also improperly, quite different theories are brought together which, to name a few, range from Piaget's genetic epistemology (1950) to Kelly's construct theory (1955). ), to the approach attributable to Berger and Luckman (1966), to the approach outlined through the hypothesis of socio-cognitive conflict by the researchers of the Geneva school (Doise, Mugny, 1981), to the autopoietic perspective of analysis of living systems by Maturana and Varela (1980), to the reflection conducted by von Foerster (1981) on "observing systems". In order to make explicit the heterogeneous nature of the contents gathered behind the term constructivism, sometimes its plural is used; thus the expression "constructivisms" acts as a label which, without giving up the idea of some form of unitary frame, signals the presence of different approaches contained in it.
\end{abstract}




\begin{abstract}
Italian)
II "costruttivismo", nelle scienze sociali, è un grande contenitore dove

convenzionalmente, ma anche impropriamente, vengono fatte confluire teorie alquanto diverse che, per citarne alcune, vanno dalla epistemologia genetica di Piaget (1950), alla teoria dei costrutti di Kelly (1955), all'approccio riconducibile a Berger e Luckman (1966), alla impostazione delineata attraverso l'ipotesi del conflitto socio-cognitivo da parte dei ricercatori della scuola di Ginevra (Doise, Mugny, 1981), alla prospettiva autopoietica di analisi dei sistemi viventi di Maturana e Varela (1980), alla riflessione condotta da von Foerster (1981) sui "sistemi che osservano". Per esplicitare il carattere eterogeneo dei contenuti raccolti dietro al termine costruttivismo, si fa, a volte, ricorso al suo plurale; così l'espressione "i costruttivismi" funge da etichetta che, senza abdicare all'idea di una qualche forma di cornice unitaria, segnala la presenza di differenti impostazioni in essa contenute.
\end{abstract}

\title{
The construct ... isms
}

"Constructivism", in the social sciences, is a large container where, conventionally, but also improperly, quite different theories are brought together, which, to name a few, range from Piaget's genetic epistemology (1950) to Kelly's construct theory (1955), to the approach attributable to Berger and Luckman (1966), to the approach outlined through the hypothesis of socio-cognitive conflict by the researchers of the Geneva school (Doise, Mugny, 1981), to the autopoietic perspective of analysis of living systems by Maturana and Varela (1980), to the reflection conducted by von Foerster (1981) on "observing systems". In order to make explicit the heterogeneous nature of the contents gathered behind the term constructivism, sometimes its plural is used; thus the expression "constructivisms" acts as a label which, without giving up the idea of some form of unitary frame, signals the presence of different approaches contained in it.

But the area of epistemological, theoretical and methodological reflection that is concerned with the analysis of the processes through which people "build" the world around them now presents such inhomogeneity that it can no longer be contained in a single word, not even declined to plural.

"Radical constructivism", "socio-constructivism", "constructionism", "socio-constructionism", "psycho-constructionism" are the terms that different authors have coined to underline, from time to time, the specificity of one approach compared to others. The multiplication of terminological derivations from the Latin root "construo" and of the adjectives chosen to qualify them is not only indicative of the inhomogeneity of positions that now characterises this area of reflection and research, but also raises legitimate doubts about the denotative power of terms such as "build" and "construction", since the differences concern precisely what is meant by "building" or "construction".

We owe to von Glasersfeld the attribution of "radical" to constructivism. Going back to the cognitivist tradition according to which it is not the world as it is that determines action, but the cognition that individuals have of the world, he draws within that perspective a distinction between a representational and a constructivist conception of knowledge. For von Glasersfeld, "radical constructivism, thus, is radical because it breaks with convention and develops a theory of knowledge in which knowledge does not reflect an 'objective' ontological reality but exclusively an ordering and organization of a world constituted by our experience "(1984, p. 24). 
The adoption of the term "socio-constructionism" (Gergen, K., 1985), on the one hand, and the juxtaposition of "social" with constructivism, on the other, indicate a distancing precisely from radical constructivism. The emphasis that the latter places on the cognitive processes of subjects never considered in interaction with others ends up reducing "the social world to a projection or an artefact of the individual cognizer." (Gergen, K., 1989, p. 465). Starting from this critique, socio-constructionists and socio-constructivists emphasize the social nature of knowledge and the importance of the interactive processes through which it is generated. However, if the adjective "social" unites them, the terms constructivism and constructionism are adopted precisely to underline a difference between those who, the socio-constructivists ${ }^{1}$, while emphasising the social nature of knowledge and therefore studying its genetic processes, continue to deal with its function in the construction processes of social realities, and who, the socio-constructionists ${ }^{2}$, suggest abandoning any analysis of cognitive processes to focus attention on the constructive function of written and spoken language. The difference is especially emphasised by constructionists who define themselves as interested in "socially constrained discourse" and attribute to socio-constructivists an interest in "internal cognitive discourse" (Gergen, M., 1989).

But even the terminological articulation does not exhaust the theoretical divergences present in this research area. The same labels of "socio-constructionism", "socio-constructivism" and "radical constructivism" cover relevant disparities of accents and emphasis between the positions of the same authors who adopt them to designate their own approach (see in this regard respectively: Pearce, 1990; the September-October 1989 issue of the European Journal of Social Psychology; Kenny and Gardner, 1988).

Yet the differences don't end there. Rijsman and Stroebe (1989) draw a distinction that crosses all "construct...isms". With one eye on the theoretical level and one on the methodological level, they distinguish between two areas of authors: those who, adopting a constructivist or constructionist theory, also reflect on the implications it has with respect to the paradigms of investigation and invite the development of research methods consistent with the reference theory (e.g. Gergen, K., 1989); and those (defined as psycho-constructionists) who, while following a constructivist or constructionist theory, adhere to the traditional paradigm of investigation of experimentalism (for example Doise, 1989).

In the area of "construct .... isms" different perspectives are therefore contrasted. These are different focuses which, although organised through an articulated theoretical elaboration, echo well-known and rooted dualisms: symbolic processes and social dynamics, knowledge and social practice, cognition and interaction ... epistemology and ontology.

But in the panorama of research and reflection on how people "construct" the world around them, there are perspectives that go beyond these dualisms. Authors like Moscovici and Bateson are good examples of such perspectives

Moscovici is interested in the "central and fascinating problems that are situated at the intersections" (1989, p. 410); Bateson deals with "phenomena that manifest themselves on an interface" (Bateson \& Bateson, 1987, p. 39), that is, with those problems or phenomena for which any dualistic approach would prove to be in vain. Symbolic processes and social dynamics, knowledge and social praxis, cognition and interaction, epistemology and ontology are faces or paths: the cited authors turn their attention and direct our attention to the interface and intersections that connect them. 


\section{Epistemology and epistemologies}

The interest that Bateson has for Epistemology with a capital E, that is, for "the science that studies the process of knowing" ( Bateson \& Bateson, 1987,p. 20), leads him to deal with epistemologies with a lowercase e, that is, with local epistemologies, personal ones and those shared by specific social groups. This landing is not accidental, it is prefigured in the distinction he draws between epistemology understood as the philosophical study of "how knowledge is possible" and epistemology understood as the study of "how knowledge is done" (Bateson \& Bateson, 1987, p. 20). And it is the option that he operates in favour of the second definition proposed, that is of an epistemology that is identified with the study of knowledge conceived as a process rather than as an object, which leads him to reflect on local epistemologies, on what he also called habits of thought, networks of presuppositions, preconceptions, premises and, in the first writings, apperceptive habits. These are all terms with which Bateson designates the organising principles of knowledge that are reflexively connected to behaviours in the process of building reality.

In the natural history of the living human being, ontology and epistemology cannot be separated. His (commonly unconscious) beliefs about what sort of it is will determine how he sees it and acts within it, and his way of perceiving and acting will determine his beliefs about its nature. The living man is thus bound within a net of epistemological and ontological premises which - regardless of their ultimate truth or falsity, become partially self-validating for him (Bateson, 1972, p.314).

But see also this formulation of the same concept:

The ideas [that people share] about nature, however fantastic, are supported by their social system; conversely, the social system is supported by their ideas of nature. It thus becomes very difficult for the people, so doubly guided, to change their view either of nature or of the social system. For the benefits of stability, they pay the price of rigidity, living, as all human beings must, in an enormously complex network of mutually supporting presuppositions (Bateson, 1979, p. 154).

The framework within which Bateson deals with the organising principles of knowledge can therefore be briefly outlined through three fundamental points: 1 ) the constructive role of the individual in his relationship with the environment; 2) the self-referential nature of cognitive processes; 3) the consensual nature of the epistemological premises that preside over the construction of reality.

These three points are, with different emphases and accents, found in all construct... isms. While they constitute the lowest common denominator of the research of von Foerster, Maturana and Varela and also of the socio-constructivists, von Glasersfeld's radical constructivism is articulated mainly around the first two points and the socio-constructionists focus their attention on the third.

Bateson, on his part, raises and asks us questions which take on particular relevance in the field of social sciences and define his position with respect to constructivism. His attention is in fact centred:

1) on the interactive processes through which epistemologies with a lowercase e are generated; that is, on the origin of consensuality, and on consensuality as a result of communicative dynamics;

2 ) on the interactive processes through which local epistemologies are maintained, and therefore on the process of self-reference, and on self-reference as a process;

3) on the interactive processes through which epistemologies change, thereby tackling a knot that in the constructivist perspective risks assuming the configuration of the impasse (Fruggeri and Matteini, 1991). The crux is this: how the processes of innovation and change are generated within the self- 
validation and reflexivity that characterise the net of epistemological and ontological premises within which every living being, but also every social system, is bound?

Through these questions, consensuality, self-reference and change are no longer just explanatory concepts of the social dynamics, but they become social processes, they themselves become the social dynamics.

\section{Consensuality, self-reference and change as social processes}

It is precisely in asking these questions that the reflection on local and personal epistemologies, on the network of premises, on the constructive processes of reality, irreducibly intertwines with the reflection on social interaction.

Every human individual -every organism- has his or her personal habits of how he or she builds knowledge, and every cultural, religious or scientific system promotes particular epistemological habits.

Bateson \& Bateson, 1987, trans. It. P. 20

And this, in relation to the fact that every cultural, religious, scientific, social system is characterised by particular learning contexts within which different epistemological habits are generated. All of Bateson's anthropological studies are guided by this idea: particular epistemological habits are associated with particular types of social interaction. So if on the one hand

.. the local epistemology, that is the aggregate of presuppositions underlie all communication and interaction between persons, even in dyads, groups of only two members

Bateson \& Bateson, 1987, trans. It. p. 97

on the other hand, reflexively, local epistemology, the network of presuppositions, preconceptions are generated within communication and social interactions.

The learning of life contexts is a matter that has to be discussed not internally, but as a matter of the external relationship between two creatures. A relationship is always a product of a double description.

Bateson, 1979, p. 142

It is through the articulation of this irreducible intertwining between symbolic processes and social interaction that Bateson finds himself in a different position both with respect to authors who call themselves radical constructivists and to those who call themselves socio-constructionists. In fact, while the former ${ }^{3}$ insist on the cognitive processes that preside over the construction of reality, the latter emphasise the constructive function of interactive and communicative processes regardless of any cognitive process.

Bateson, instead, draws an interconnection between knowledge and social processes that indicates a perspective from within which one cannot analyse how epistemological premises intervene in the construction of social realities without simultaneously understanding in the analysis the social interactions that generate the epistemological premises that converge in the processes of construction of social realities. In this sense, the Batesonian approach presents, if anything, an analogy 
with the socio-constructivist one, which in fact has particularly investigated how representations intervene in the construction of social interactions and how social interactions generate particular "habits" of thought (Farr and Moscovici, 1984). However, with respect to this, some differences are also present, and they can be found above all on a methodological level.

Bateson intertwines the reflection on social construction processes with the reflection on how one reflects on these processes. The two levels are inextricably connected, just Epistemology with a capital $E$ and epistemology with a lowercase e are inextricably connected. Reflection upon reflection does not end in the self-reflexivity suggested for example by von Glasersfeld (1984), that is, in the reflection on one's own premises, which ends up translating into an endless regression: on the basis of which final premises do we analyse our premises?

Bateson writes: "The manner of search is plain to me and might be called the method of double or multiple comparison" in which, as he explains, information of different kinds and from different sources is combined (Bateson, 1979, p. 91-92). The method of double description combines the information coming from the analysis of construction processes with that coming from the analysis of the interaction that develops in analysing the construction processes. The reflection upon reflection that Bateson suggests it's not therefore fed by the tension towards awareness, but by the making of the relationship that every cognitive operation constitutes.

The term challenge has been used and abused in recent years, however in the case of Bateson it is not rhetorical to say that with the perspective of the double description he has opened a challenge that as social scientists we still have many difficulties to take up.

But let's get to the second point, the process of self-reference.

If "it is not correct to say: 'you see me', because what you see is an image of me", for Bateson, it would however be nonsense "to claim that you construct these images" because "we have no knowledge on the process by which in our perception images are formed" (in Bateson \& Bateson, 1987, p. 88). And he specifies: "... how you perceive is governed by a system of presuppositions I call your epistemology: a whole philosophy deep in your mind, but beyond your consciousness" (in Bateson \& Bateson, 1987, pp-93-94).

The unawareness of this epistemology, to which Bateson dedicated beautiful pages (see 1978a, $1978 b, 1987)$, is a constitutive element of the perceptual process itself:

Unconscious epistemology - the how of using our senses - is a deeply concealed body of knowledge; and the concealment of that knowledge comes between the conscious understanding and the external world to make us sure of the reality of "self".

Bateson, 1978, p. 57

Without the unawareness of the premises that govern perception, the same conditions for which the perceptual process can take place would be missing; there wouldn't be "self", self-reference, there would be doubt and uncertainty; in fact there wouldn't be the relationship constituted through perception and through which perception is realised. In this sense, we can say that self-reference is fuelled by the unawareness of the premises that originate it and as such unawareness guarantees the communication and stability of our constructions of reality.

The lack of awareness of the epistemological premises lives in what Bateson calls faith, sacred, the 
place where "even angels fear to tread".

The introduction of the theme of the sacred is an example of the displacement that Bateson usually operates towards his interlocutors. It warns us not to go to the place where the angels hesitate, as if it were a place we couldn't reach, but then he tells us immediately afterwards that this is a place where we "are", a place that we constantly build and reconstruct through social dynamics in which we participate. Rituals, mythologies, mystifications are some of the social practices through which the necessary unawareness of certain epistemological premises is maintained (in Bateson \& Bateson, 1987).

Self-reference contrasts the vision of a world in which "you would cease to exist, becoming nothing but a metaphoric feather blown by the winds of external 'reality'"; but the idea of self-reference for Bateson has nothing to do with a world in which "you are ultimately isolated and alone, isolated by the premise "I make it all up". Self-reference is placed in the network of social and interpersonal dynamics through which unawareness and therefore the stability of the systems of presuppositions are built and reconstructed. In that "region where you are partly blown by the winds of reality and partly an artist creating a composite out of the inner and outer events" (Bateson, 1977, p. 245).

However, Bateson wonders not only about stability, but also about change. And also, the question about the processes of innovation is placed by him in the intertwining of epistemological premises and social interaction.

Any change in our epistemology will involve .... crossing the threat of that chaos where thought becomes impossible

Bateson, 1979, p. 153-154

But the threat of that chaos where thinking becomes impossible is generated within specific types of social interactions, what Bateson has called Double Binds. Beyond the numerous distortions that have been made of this concept (in particular by confining its validity in the clinical context), the double bind is that particular type of relationship within which the rules through which the meaning of the relationship is built can no longer function. That particular type of social interaction that produces dissonance, a socio-cognitive conflict responsible for conditions, as Bateson says, of discomfort and suffering. Creativity and innovation are the result of processes activated to overcome this discomfort (Bateson, 1978).

Overall, the one proposed by Bateson is a perspective within which symbolic processes and social interactions emerge as embraced. It is a perspective that combines two points of view that in the field of social sciences, but not only, have traditionally been separated: the emphasis on interactive processes, which has led to objectivistic analyses, and that on symbolic processes, which has ended up building an individualistic approach. But even some of Bateson's best known interpreters have placed themselves on one or the other pole: think of Watzlawick and colleagues and their behaviourist declination of the theory of communication (1967); or think of the simplification that others have reached when, starting from Bateson's statement: "it is not so much power that corrupts, but the idea of power" (Bateson, 1978, trans. It. p. 486), they concluded that power does not exist.

On one side, it is legitimate to formulate the doubt about the rebirth of a pragmatic neointeractionism in the face of the goal that the socio-constructionists declare to elaborate a model of analysis of psycho-social phenomena that is coherently separate from cognitivism (Potter and Wetherell, 1987). On the other side, it cannot be ignored that the socio-constructivists and some of 
the radical constructivisms also combine the autonomy of cognitive processes with the relationship. However, in radical constructivisms or in the discussion of these constructivisms, the community (von Foerster, 1981) or the consensual domains (Maturana and Varela, 1980) remain in the background of the cognitive operations of a subject / observer who ends up remaining a bit alone in the centre of a picture, actually rather empty.

\section{Observers, researchers, social actors}

The constructive character of the observer is certainly at the centre of Bateson's approach, as it is in the various construct...isms described above. The small experiment with which Bateson begins the essay "Pathologies of epistemology" (1972) is well known: he asks the audience the question "Do you see me?" to make it immediately clear that what his interlocutors see is only an image of him. Just as Maturana begins his lessons by drawing the observer's eye on the blackboard. However, we can say that the different construct...isms are populated by different observer figures. I would like to indicate at least two:

1) the observer defined in the context of her cognitive operations;

2) the observer defined in the context of the social relations in which she participates, thus a social actor

The first is an observer who builds reality around herself in solitude. The relationship is dyadic: observer-reality, and in this dyad reality is the non-specific pole. The constructions, the observer's operations, concern objects of which it is not defined whether they are physical or social, individual or collective. It is an observer with no history and all we know of her are the construction operations at a given moment. The context of the constructions is not considered.

She is an observer who sees, who imagines, who describes, who acts, but who almost never feels or touches, nor feels emotions.

She is an observer whose discussions always end up polarising around the inevitable question "does reality exist or does not exist?"

The scientist who identifies with this observer ends up feeding on self-reflexivity or becoming paralysed. The further alternative is obviously to deny yourself as a scientist.

I will describe in Bateson's words the figure of the second observer/social actor:

We are not concerned with a hypothetical individual in contact with an impersonal events stream, but rather with real individuals who have complex emotional patterns of relationships with other individuals. In such a real world, the individual will be led to acquire or reject apperceptive habits by very complex phenomena of personal example, tone of voice, hostility, love, etc. Many such habits, too, will be conveyed to him through his own naked experience of the stream of events, for no human beings (not even scientists) are naked in this sense. The events stream is mediated to them through language, art, technology and other cultural media which are structured at every point by tramlines of apperceptive habits

(Bateson, 1972, trans. It. p. 208) 
This observer constructs reality from within a network of relationships, in which the cognitive, emotional and affective aspects are constitutive elements intertwined with each other and with the institutional aspects. She is an observer who has history and her history is the history of the dense network of emotional and institutional relationships of which she is a part. She is precisely an observer whose cognitive operations can only be investigated in the intertwining with the social dynamics in which she participates. More than just observer she is a social actor.

But this observer/social actor is also we who investigate.

In social psychology, Farr points out, "... the experimenters were content to demonstrate how the representations that their subjects form in the experimental situation influence the way they act within the laboratory situation. ... 'but they have never studied' ... the way of operating social representations at the level of the scientific community "(1984, trans. It. pp. 164-165).

As Morin says: "There is a scientific method to take into consideration and under control the objects of science. But there is no scientific method to consider science as an object of science and even less the scientist as the subject of this object "(1977, trans. It. p. 18).

Well, the questions that Bateson asks himself and us indicate that this method will in any case have to take into account the emotions, the representations, the network of relationships of the scientist and include them as constitutive elements of that social process that the scientific community calls research.

This implies as a first step to stop thinking that the world of science is a reified world, but also that it is an aggregate of observers in solitude. The world of science, despite having its own language, its conventions that are different from the world of common sense, is, like this, a consensual world which, through social practices, such as conferences, publications, university competitions, the affective relations between colleagues, whether they are set to hostility or harmony, builds and elaborates social representations, premises, presuppositions, more or less widely shared preconceptions that govern the construction of investigations whose results are the product of co-construction of the researchers and the research participants.

All this implies an overcoming of the conception of research as a representation of reality, but also of research as a product of an observer; and it implies instead a conception of research as social interaction, within which how the representations of the subjects involved originate, are maintained and change become the questions that matter.

Raising these questions commits researchers to take a binocular point of view: the attention to the object of investigation is intertwined and integrated with the attention directed to the interactive processes through which research is carried out. The methodological problems related to the analysis of these processes are still open, but the attempts made so far to address them, however episodic, allow us to glimpse the fruitfulness of this little explored field. The analysis made on the process of negotiation of meanings that takes place, through the conversation, between researcher and participants, in the experiments of Developmental Psychology and in Cognitive Psychology have thrown a different light on the same results of the experiments and have paved the way for different and new investigative hypotheses (see Trognon, 1992). The study of the reflexivity between actions and meanings in the interactive processes to which the researcher and participants give shape, has also highlighted the effects that are produced as a result of the coordination of their systems of representation, independently of their intentions. According to these studies, the interaction through 
which research takes place constructs social meanings and realities beyond the unilateral control of both researchers and participants (Lannamann, 1991).

Conversational analysis and the analysis of the unintended effects of interactions constitute two different investigation procedures on research understood as a joint action of researcher and subject. In Social Psychology they are currently at the centre of a lively and not at all linear debate.

In general, they can be considered as the first steps in the direction of overcoming what Morin calls the inability of science to understand itself as a social practice.

\section{Notes}

1. Socio-constructivism refers here to a rather broad area of research on the articulation between mental and social processes which includes studies on cognitive development processes that are part of the Geneva school (in addition to Doise and Mugny, 1981, also Perret Clermont, 1980 and Emiliani and Carugati, 1985, among others); the theory of social representations (Moscovici, 1961, 1981, 1983, 1988, Farra E Moscovici, 1989, Jodelet, 1989a, 1989b, among others); the genetic model of social influence processes (Moscovici, 1979, Perez and Mugny, 1989).

2. Among the authors who use the term socio-constructionism to define their own approach and who have tried most to clarify the differences with the area identified with the label of socio-constructivism, see in particular Gergen, 1985,1988 , 1989; Gergen, M., 1989; Gergen and Shotter, 1989; Harré, 1989; Shotter, 1990; Potter and Wetherell, 1987.

3. Although it is only von Glasersfeld who explicitly uses the term Radical Constructivism to identify his own approach, and while acknowledging the differences between the various authors, von Foerster (1981) and Maturana and Varela (1980) are also included here under the same label. , 1987).

\section{References}

Bateson, G. (1972). Steps to an ecology of mind. Ballantine, New York (Italian translation. Towards an ecology of the mind, Adelphi, Milan, 1976).

Bateson, G. (1977). "Afterword", in J. Brockman, ed., About Bateson, Wildwood House, London, pp. 235-247.

Bateson, G. (1978). "The birth of a matrix or double bind and epistemology", in M. M. Berger, ed., Beyond the double bind, Brunner \& Mazel, New York, pp. 39-64.

Bateson, G. (1979). Mind and nature: A necessary unity, Dutton, New York (transl. It. Mind and nature: A necessary unit, Adelphi, Milan, 1984).

Bateson, G., Bateson M.C. (1987). Angels fear: Toward an epistemology of the sacred, Macmillan, New York (Italian translation. Where the angels hesitate, Adelphi, Milan, 1989).

Berger, P., Luckman, T. (1966). The social construction of reality, Garden City, N. J., Doubleday (transl. It. Reality as social construction, Bologna, II Mulino, 1969).

Doise, W. (1989). "Constructivism in Social Psychology", in European Journal of Social Psychology, n. 19, pp. $389-400$

Doise, W., Mugny, G. (1981). Le développement social de intelligence, Paris, Interéditions (trad. It. The social construction of intelligence, Bologna, II Mulino, 1982). 
Emiliani, F., Carugati, F.F. (1985). The social world of children, Il Mulino, Bologna.

Farr, RM (1984). "Role of social representations in the design and execution of laboratory experiments", in, Farr, RM, Moscovici, S., eds., Social representations, Cambridge University Press, Cambridge (trad. It. " Role of social representations in the design and execution of laboratory experiments ", in RM Farr, S. Moscovici, edited by, Social representations, II Mulino, Bologna, 1989, pp. 153-177).

Farr, R. M., Moscovici, S., eds., (1984). Social representations, Cambridge University Press, Cambridge (trad. It. Social representations, II Mulino, Bologna, 1989).

Fruggeri, L., Matteini, M. (1991). "Structure and levels of narration", in V. Ugazio, edited by, Emotions, subject, systems, Life and Thought, Milan, pp. 67-83.

Gergen, K. (1985). "The social constructionist movement in modern psychology", in American Psychologist, no. 40, pp. 266-275.

Gergen, K. (1988). "Knowledge and social process", in D. Bar-Tal, A.W. Kruglanski, eds., The social psychology of knowledge, Cambridge University Press, Cambridge, pp. 30-47.

Gergen, K. (1989). "Social psychology and the wrong revolution", in European Journal of Social Psychology, n. 19, pp. 463-484.

Gergen, M. (1989). "Induction and construction: Teetering between words", in European Journal of Social Psychology, n. 19, pp. 431-437.

Harré, R. (1989). "Language games and the texts of identity", in J. Shotter, K. Gergen, eds., Texts of identity, Sage, Lonson, pp. 20-35.

Jodelet, D., ed., (1989a). Les rapresentations sociales, Puf, Paris.

Jodelet, D. (1989b). Folies et repésentations sociale, PUF, Paris.

Kelly, G. (1955). The theory of personal constructs, New York, Norton.

Kenny, V., Gardner, G. (1988). "Constructions of self-organizing systems", in The Irish Journal of Psychology, n. 9, pp. 1-24.

Lannamann, J. W. (1991) "Interpersonal communication research as ideological practice", in Communication Theory, n. 3, pp. 179-203.

Maturana, H., Varela, F. (1980). Autopoiesis and cognition, Reidel, Dordrecht, Holland (translated. Autopoiesis and cognition, Marsilio, Venice, 1985).

Maturana, H., Varela, F. (1987). The tree of knowledge, Garzanti, Milan.

Morin, E. (1977). La méthode. I. La nature dela nature, Seuil, Paris (trad. It. The method: Order disorder organization, Feltrinelli, Milan, 1983).

Moscovici, S. (1961). La psychanalise, son image et son public, Puf, Paris.

Moscovici, S. (1979). Psichologie des minorités actives, Puf, Paris (trad. It. Psychology of active minorities, Boringhieri, Turin, 1983).

Moscovici, S. (1981). "On social representations", in J.P. Forgas, ed., Social cognition, Academic Press, London.

Moscovici, S. (1983). "The coming era of social representations", in J.P. Codol, J.P. Leyens, eds., Cognitive analysis of social behavior, Martinus Nijhoff, The Hague. 
Moscovici, S. (1988). "Notes toward a description of Social Representations", in European Journal of Social Psychology, n. 18, pp. 211-250.

Moscovici, S. (1989) "Preconditions for explanation in Social Psychology", in European Journal of Social Psychology, n. 19, pp. 407-430.

Pearce, B. W. (1990). "A camper's guide to constructionisms", manuscript, 1990.

Perez, J., Mugny, G. (1989). Psychology of social influences, Promolibro, Valencia.

Perret-Clermont, N. (1980). Social interaction and cognitive development in children, Academic Press, London.

Piaget, J. (1950). Introduction à l'épistémologie génétique, tome I, II, III, Paris, PUF.

Potter, J., Wetherell, M. (1987). Discourse and social psychology, Sage, London.

Rijsman, J., Stroebe, W. (1989). "Introduction: The two social psychologies or whatever happened to the crisis?", In European Journal of Social Psychology, n. 19, pp. 339-344.

Shotter, J., Gergen, K, eds., (1989). Texts of identity, Sage, London.

Shotter, J. (1990). Knowing of the third kind, ISOR / University of Utrecht, Utrecht.

Trognon, A. (1992). "Cognitive psychology and analysis of conversations", in C. Galimberti, edited by, The conversation, Guerini Studio, Milan, pp. 115-155.

Watzlawick, P., Jackson, D., Beavin, J. (1967). Pragmatics of human communication, Norton, New York. von Foerster, H. (1981). Observing systems, Intersystems Publications, Seaside, Ca. (trans. It. Observing systems, Astrolabio, Rome, 1987).

von Glasersfeld, E. (1984). "An introduction to Radical Constructivism", in P. Watzlawick, ed., The invented reality, Norton, New York, pp. 17-40 (transl. It. "Introduction to radical constructivism", in, P. Watzlawick, edited by, The invented reality, Feltribelli, Milan, 1988).

\section{Author}

Laura Fruggeri, $\mathrm{PhD}$, is a systemic/social constructionist therapist, supervisor, consultant and researcher. She was Professor at the University of Parma teaching Psychology of Family Relations and is currently Director of the Centro Bolognese di Terapia della Famiglia in Bologna, Italy. She has presented at several national and international conferences, seminars and training courses. She is author of more than a hundred publications in Italian, English, French, Spanish, and German.

Email: laura.fruggeri@gmail.com

URL: https://www.terapiafamiliare.org 


\title{
Four reflections on the new English translation of the 1994 Italian paper, "Social Research as a Process of Interaction" by Laura Fruggeri
}

\author{
Reflections from Sharon Bond, Sheila McNamee, Hugh Palmer and Gail Simon
}

\section{Sharon Bond:}

Reading this article re-connected me to the experience of doing my doctorate research. I wanted to explore what was happening in the education system that was resulting in so many black children, especially black boys, being excluded from school and from formal education. I was particularly interested in primary school aged black boys who were beginning to make up an increasing number of my caseload in the Child and Adolescent Mental Health Service (CAMHS) where I worked. I also had a personal interest in this area of research as the parent of a black boy and being part of a community of black parents with black children. Although my son was now an adult I recalled conversations where I had been summoned to the school to account for his behaviour.

The literature available at that time presented a variety of reasons for the rising numbers of black children being excluded from school. They gave psychological reasons, among them low intelligence due to race and sociological reasons which cited poverty with race and racism as contributory factors. These psychological and sociological explanations did not explore the everydayness of experiences of race and racism and how that informed the decision-making process for black children and parents in their interaction with schools and teachers. Neither did they explore in any depth the construction of the ideological pillars on which theories of race are built, supported and validated.

When I decided to research the exclusion of black boys from school I called what I was doing action research. I wanted to explore how societal stories told about Black People influenced the stories that black people could tell about their lives and in turn whether research like mine could change the dominant story sufficiently to bring about structural change. The reaction I received to my proposal was the question "Are you a campaigner or a researcher?" I understood this as an invitation to rethink my ideas about the method and methodology for my research. It made me question what was important for me here - i.e. what was the cost of pursuing research that had the potential to bring hidden or "subjugated' knowledges, stories or discourses" (Afuape \& Hughes, p. 29) to the fore; whether compromise was possible and what that would look like.

Fruggeri's article raises concerns about the theories and methodologies we have for researching how people "build" or "construct" the world in which their lives are lived. The article explores the many faces of "construction....isms" looking at what Burr $(2003$, p. 2 ) calls their "family resemblance". It appears to question whether "construction....isms" in its different articulations provides a sufficiently robust theoretical and methodological framework for researching phenomena situated "at the interface and intersections".

She points to the distinction made by Bateson on the difference between Epistemology with an ' $E$ '; the science that studies "how particular organisms or aggregates of organisms know think and decide" and epistemology with an ' $\mathrm{e}$ ' which concerns itself with knowledge that is local and based on "habits of thought, networks of presuppositions, preconceptions, and premises" to argue for the importance 
of having an organising principle that reflexively connects behaviour and beliefs to the process of building reality.

The question I find myself grappling with at this point in the commentary is: which direction should I take this conversation. I think Fruggeri's observations and articulation of Bateson's position and the quotations she uses to frame her thinking, are interesting and pertinent. My only reservation is that this remains at a level of abstraction. My thinking is that this needs grounding in real life stories and possibilities. Why does this matter to me? Because I think what is being explored here is more than research theory and methodology. I believe it is about power relationships - "the phenomena situated at the interface and intersections".

I am mindful that power relationships are also at the heart of movements concerned with the effects of climate change on the environment and the meaning of Black Lives Matters. I am aware that these movements have collected data which have been analysed and disseminated and represent information that has added to the body of knowledge that show how we, in Bateson's words, "do" epistemology with a capital ' $E$ ' intertwined with epistemology with a small ' $e$ ' to construct or build our social world. These movements are more commonly described as "protest movements" and their objectives to bring about structural change named activism. In my mind this poses the question about the nature of research. I wonder when research becomes activism and when activism becomes research? Is there a continuum with research at one end and activism at the other? If so, is activism a necessary condition for change?

\section{References}

Afuape, Taiwo \& Hughes, Gillian (2016). Liberation Practices: Towards emotional wellbeing through dialogue. Abingdon, Oxon: Routledge.

Burr, Vivien (2003) Social Constructionism. Abingdon, Oxon: Routledge.

\section{Sheila McNamee:}

It is challenging to question the canonical image of science and research. The two terms are united as is a hand with a glove. In her article, Social Research as a Process of Interaction, Laura Fruggeri engages in a detailed discussion about the various (and often competing) versions of constructivism. She also addresses the distinction between constructivism(s) and constructionism. This discussion is aimed at challenging the traditional view of research. What Fruggeri makes clear is that we must recognize research as a process of human interaction. Her position pulls the curtain back on the Wizard of $\mathrm{Oz}$ image of the researcher.

If we accept the social nature of knowledge (i.e., that knowledge is socially constructed in interaction) and thereby recognize the centrality of interactive processes, then we begin to blur the traditional distinction between research and social change (e.g., consultation, program development, etc.). There is a transformative potential of inquiry. We recognize the ways in which all social action rests within a matrix of relationships with other actors. Research focused on the social world, unlike research focused on the material world, is not about discovery since the questions we ask and the methods we employ simultaneously expand and limit future possibilities. In this sense, we can say that social 
research is a process of creating a world and thus creating a future.

Research is described as a relational process where the coordination of multiple (and often competing) discourses are at play. The challenge for the researcher is to adopt a reflexive stance toward any inquiry process so that the local, contingent, and situated practices of those participating in the research, as well as those conducting the inquiry, can be in dialogue with one another. From a constructionist stance, traditional research (i.e., the scientific method) is viewed as one discursive option for conducting research - but not the only one.

Fruggeri's point that science is bound by various communities of practice - where, just like any other social community, assumptions, beliefs, and values are negotiated - is critically important to our understanding of what kind of process we are engaged in as researchers (McNamee \& Hosking, 2012). What constitutes legitimate research is viewed differently across different communities of scholarship. We can refer to any distinct way of understanding and conducting research, including its unique purposes, practices, and conventions of rigor-together with the beliefs, assumptions and standards of the professions and communities of scholarship within which it is situated-as a research world (McNamee, 2014). The Diagnostic research world is aligned with the traditional orientation to research in, for example, psychotherapeutic care and has origins in natural sciences; Interpretive research is well accepted in many domains and has origins in social sciences; Relational research is an emerging orientation that views research as having a legitimate purpose of social transformation. Each world is coherent and has well developed standards of rigor when viewed within its own community yet may seem inconsistent and puzzling when viewed across worlds.

\section{References}

McNamee, Sheila \& Hosking, Dian Marie (2012). Research and social change: A relational constructionist approach. New York: Routledge.

McNamee, Sheila (2014). Research as relational practice: Exploring modes of inquiry. In G. Simon \& A. Chard (Eds.), Systemic inquiry: Innovations in reflexive practice research.

\section{Hugh Palmer:}

I have really enjoyed the opportunity to read this first English translation of Laura Fruggeri's 1994 paper. It offers an invaluable opportunity to consider threads between Bateson's original writing from the 1970s, Laura's remarkably insightful and relevant consideration of Bateson in terms of constructivism and constructionism, and now in 2020, connecting with further ontological and epistemological turns, in particular, the concept of Transmaterial Worlding (Barad, 2007; Salter \& Simon, 2019).

I remember trying to help systemic trainees understand the distinction between constructivism and social constructionism. Asking the well-known Bishop Berkeley question (or is it a koan?) "If a tree falls in a forest and no one is around to hear it, does it make a sound?" was useful in encouraging learners to think about constructivism. I would suggest to trainees that it could be argued that the waves of pressure created by the falling tree only become sound when interpreted by creatures with 
the physiological attributes necessary to interpret those waves as sound.

I would then go on to ask people to consider how the news of pregnancy may lead to social constructions of the infant's gender even before birth, as friends and family purchase items of clothing, cards and so on, usually gendered with language and colour. I would ask them to think about how influential social constructions are in forming and shaping a person's identity throughout their life.

In hindsight, these were rather crude ways of introducing epistemological ideas of how 'realities' are constructed - either through inner cognitive processes or socially, through language.

I may have occasionally mentioned to colleagues that Gregory Bateson grappled with these ideas, although he wrote about them using language, concepts and metaphors that drew upon his own experience as an anthropologist and natural historian. I am pretty sure I may have even made the observation that Bateson was a social constructionist before the term had been coined, although technically, I was wrong. Fruggeri's chapter has helped clarify these different epistemological and ontological approaches, and carefully considered how Bateson's thinking might be positioned in relation to them. His thinking spanned what might be called constructivist, social constructivist and social constructionist and he also understood that epistemology and ontology (knowing and being) are inseparable.

Laura Fruggeri notes Bateson understood that individuals build knowledge through a recursive relationship between both cognitive processes and social interaction. His cybernetic epistemology does not allow the duality of either/or of the primacy of cognitive processes or social interaction. She also identifies that Bateson considered that our perceptive processes are necessarily unconscious, which enables us to have a sense of "self".

How I know what I know, then, is a process that is mediated by my perception (which is largely unconscious - I don't consciously "see" or "hear"), my cognitions, my relationships and the context in which I live. My knowing is in part self-referential and based upon unconscious, conscious, relational and contextual processes. My knowing is both epistemological and ontological. As Bateson (1972, p. 314) observed:

In the natural history of the living human being, ontology and epistemology cannot be separated. His (sic) (commonly unconscious) beliefs about what sort of world it is will determine how he sees it and acts within it, and his ways of perceiving and acting will determine his beliefs about its nature. The living man is thus bound within a net of epistemological and ontological premises which-regardless of ultimate truth or falsity-become partially self-validating for him...I shall therefore use the single term "epistemology" in this essay to cover both aspects of the net of premises which govern adaptation (or maladaptation) to the human and physical environment. In George Kelly's vocabulary, these are the rules by which an individual "construes" his experience.

While Bateson was undoubtedly aware of Kelly's constructivist "personal construct psychology", he was more aligned with the work of Kurt Lewin (with whom he collaborated), whose field theory conceived of the whole psychological situation of the individual as being one part of a whole situation, 
or Gestalt, both personal and environmental (Harries-Jones, 2016).

Given that Bateson considered that our epistemology governs how we adapt to, and construe our world, we also need to heed his warning (1972, p. 343):

If we continue to operate in terms of a Cartesian dualism of mind versus matter, we shall probably also continue to see the world in terms of God versus man; elite versus people; chosen race versus others; nation versus nation; and man versus environment. It is doubtful whether a species having both an advanced technology and this strange way of looking at its world can endure.

Perhaps our species won't survive, but the impact of our dualistic thinking upon wider systems cannot be ignored; other species are dying out as a result of our activities. The Anthropocene is an epoch where a single species is destroying habitats and making survival precarious for many more species, including itself. As Anna Tsing (2015, p. 20) notes:

Precarity is the condition of being vulnerable to others. Unpredictable encounters transform us; we are not in control, even of ourselves. Unable to rely on a stable structure of community, we are thrown into shifting assemblages, which remake us as well as our others. We can't rely on the status quo; everything is in flux, including our ability to survive.

Given that "mind" and "matter" are inextricably linked as processes of knowing and being, we are both within the world and creating it (worlding) at the same time as our species is destroying, or unworlding, as Haraway $(2016$, p. 56) puts it, much of our home planet. Our anthropocentric viewpoint needs challenging.

Transmaterial worlding offers a route to an urgently needed paradigm (and therefore also epistemological) shift for our species, that is in the spirit of Bateson's cybernetic epistemology as it

"...evokes ecological and contextual curiosity and invites questions that pay attention to relational affect involving a more-than-human relating and a more-than-local focus" (Simon and Salter, 2019, p. 7).

\section{References}

Barad, Karen (2007). Meeting the Universe Halfway: Quantum Physics and the Entanglement of Matter and Meaning. Durham, NC: Duke University Press.

Bateson, Gregory (1972). Steps to an Ecology of Mind: Collected Essays in Anthropology, Psychiatry, Evolution, and Epistemology. University of Chicago Press.

Haraway, Donna (2016). Staying with the Trouble: Making Kin in the Chthulucene. Durham and London: Duke University Press.

Harries-Jones, Peter (2019). Upside-Down Gods: Gregory Bateson's World of Difference. New York: Fordham University Press.

Simon, Gail \& Salter, Leah (2019). Transmaterial Worlding: Beyond Human Systems. Murmurations: Journal of Transformative Systemic Practice, 2(2), 1-17. https://doi.org/10.28963/2.2.2

Anna Tsing (2015), The Mushroom at the End of the World. Princeton: Princeton University Press. 


\section{Gail Simon:}

When I first heard about the existence of this paper, it was in the context of a talk with Laura Fruggeri for the Systemic Lives podcast on Murmurations: Journal of Transformative Systemic Practice. She spoke about what it meant to be an Italian writer and have invitations to write in English as well as in Italian. Most of her publications are in Italian. I agree with her opinion that her greatest contribution is that she embraced social constructionism without leaving the systemic or the context of system or the work of Gregory Bateson. At some point in our conversation, I asked her which of all her papers she thought was the most important for systemic practitioners to read. She said it was a chapter in a book about Gregory Bateson in which she wrote about the different constructionisms. Writing this paper must have been a labour of love as it is a gift of rigorous mapping with discussion of some of the key linguistic terms which inform systemic practice.

I wish I had read this paper when it was first published in 1994. It would have been a good companion for me over the years. I had come across Rozanne Leppington's 1991 paper in Human Systems journal, "From constructivism to social constructionism - and doing critical therapy" and found her distinctions between constructivism and social constructionism exciting as they were so clear in framing the relationships between ideology, theory and practice. Leppington's work has featured in many papers I have written. But I suspect that if I had had this paper also as a companion it would have taken me further again into mapping ideological consequences of our choices and situatedness of theory. I have always needed to understand and make explicit the contexts I am expected or choosing to act into or out of. The exercise, in this paper, of deconstructing social construction through historic and systemic lenses (read multi-contextual) is necessary to take responsibility for knowing where one is. Otherwise one might find oneself on a slip road into another paradigm without having even realised the ideological and political consequences of the shift.

I think one particular part I would have got stuck into was the paragraph on page 83:

Moscovici is interested in the "central and fascinating problems that are situated at the intersections" (1989, p. 410); Bateson deals with "phenomena that manifest themselves on an interface" (Bateson \& Bateson, 1987, p. 39), that is, with those problems or phenomena for which any dualistic approach would prove to be in vain. Symbolic processes and social dynamics, knowledge and social praxis, cognition and interaction, epistemology and ontology are faces or paths: the cited authors turn their attention and direct our attention to the interface and intersections that connect them.

I would have focused and run with this as a challenge because in the world of early nineties systemic social construction, I felt constructivism and social constructionism were in a dualistic relationship. In some ways, social constructionism had moved "past" constructivism, replacing "cognition" with "discourse" and "thought" with "narrative". It was another attempt to emphasise a relational context and a pull away from foregrounding the biological self in favour of a discursive self. Then, as the nineties rolled on, another dualism emerged, or was it more of a split? The family jewels of narrative construction again peeled off into two schools: i) the narrative as personal construct extending the theory of Cognitive Behavioural Therapy and ii) narrative as socially constituted and socially contestable. I seem to remember this is one of the reasons Leah Salter and I decided on using the preferred term of "co-construction" in our paper on Transmaterial Worlding to capture the collaborative activity in making inclusive social worlds (Simon and Salter, 2019). 
I'm also drawn to the reflections on Epistemology and epistemology (p. 84). Of course, I am reading through the lens of Karen Barad's onto-epistemology (2007) so I am struck by whether these nouns are trying to describe a static thing or constant movement as described by Barad. This connects with some of my thoughts in the editorial of this issue and in other writings (Simon, 2012) about living in a fast-changing world which, for ideologically reflexive practitioners, necessitates openness to question at all levels of context.

The inevitability of paradigmatic whirling has massive implications for what counts as "good" professional practice and "good" research practice. Laura Fruggeri's critique of some research methods as "first steps in the direction of overcoming what Morin calls the inability of science to understand itself as a social practice" (p. 90) remains a challenge. Nevertheless, second and third steps have taken place which have developed an understanding of research for reflexive practitioners and other qualitative inquirists as studying from within the living moment of relational responsivity (For example, Ellis, 2000; McNamee and Hosking, 2012; Shotter, 1999).

This paper invites us to think of ourselves as what Fruggeri would term "social actors" (p. 88) not only by reflecting on the origins of the terms that we use as everyday shorthand but also as co-constructing fresh understandings of these terms and innovative and coherent professional and research practices to influence what we can do in our social worlds to improve social justice.

\section{References}

Barad, Karen (2007). Meeting the Universe Halfway: Quantum Physics and the Entanglement of Matter and Meaning. Durham, NC: Duke University Press.

Ellis, Carolyn (2000). Creating Criteria: An Ethnographic Short Story. Qualitative Inquiry, 6, 2, 273-277. Leppington, Rozanne (1991). From Constructivism to Social Constructionism and Doing Critical Therapy, Human Systems Journal of Consultation and Management, 2(2), 217-31.

McNamee, Sheila \& Hosking, Dian Marie (2012). Research and social change. A relational constructionist approach. London: Routledge.

Shotter, John (1999). Writing from within "living moments:" "withness-writing" rather than "aboutnesswriting". Fourth National Writing Across the Curriculum Conference: Multiple Intelligences, Cornell University, June 3rd-5th, 1999.

Simon, Gail (2012). Praction Research: A Model of Systemic Inquiry. Human Systems Journal of Systemic Consultation and Management. 23, 1, 103-124. Available at https://www.academia.edu/2169784/

Simon, Gail \& Salter, Leah (2019). Transmaterial Worlding: Beyond Human Systems. Murmurations: Journal of Transformative Systemic Practice, 2(2), 1-17. https://doi.org/10.28963/2.2.2

\section{Citation}

Fruggeri, Laura (2021 [1994]). Social research as a process of interaction, and four contemporary reflections from 2021. Murmurations: Journal of Transformative Systemic Practice, 3, 2, 81-99.

https://doi.org/10.28963/3.2.6 